University of Wollongong

Research Online

Australian Institute for Innovative Materials -

Papers

Australian Institute for Innovative Materials

$1-1-2017$

Large-scale synthesis of ternary Sn5SbP3/C composite by ball milling for superior stable sodium-ion battery anode

\author{
Wenchao Zhang \\ University of Wollongong, wz990@uowmail.edu.au \\ Jianfeng Mao \\ Chinese Academy Of Sciences, jmao@uow.edu.au \\ Wei Kong Pang \\ University of Wollongong, wkpang@uow.edu.au \\ Zaiping Guo \\ University of Wollongong, zguo@uow.edu.au \\ Zhixin Chen \\ University of Wollongong, zchen@uow.edu.au
}

Follow this and additional works at: https://ro.uow.edu.au/aiimpapers

Part of the Engineering Commons, and the Physical Sciences and Mathematics Commons 


\title{
Large-scale synthesis of ternary Sn5SbP3/C composite by ball milling for superior stable sodium-ion battery anode
}

\author{
Abstract \\ Alloy-based materials (i.e. Sn, Sb, P) are promising candidates for sodium-ion battery (SIB) anodes, but \\ they suffer from capacity decay during charge/discharge cycling due to the pulverization caused by their \\ huge volume change. Nanostructures can slow down the capacity fade, but most of the synthesis \\ methods of such nanostructured anodes are difficult to scale-up. Herein, a ternary Sn5SbP3/C composite \\ was fabricated by a green, low cost, one-step and easily scalable ball-milling of elementary $\mathrm{Sn}, \mathrm{Sb}, \mathrm{P}$, and \\ C. The microstructure of the ball-milled powders consists of micrometric agglomerates of active nano \\ Sn4P3 and SnSb and Sn particles. Carbon in the composite acts as a conducting matrix, and it does not \\ only benefit to the ball milling efficiency, but also benefit to the cycle life of the electrode. Each of the \\ active Sn4P3 and SnSb and Sn phases in the composite functions mutually as a buffer for the others. As \\ a result, this ternary composite anode delivers a good capacity of $352 \mathrm{~mA} \mathrm{~h} \mathrm{g-1}$ at the current density of 2 \\ A g-1, which is notably higher than that of the binary Sn4P3/C and SnSb/C composites produced under \\ the same conditions.

\section{Disciplines} \\ Engineering | Physical Sciences and Mathematics

\section{Publication Details} \\ Zhang, W., Mao, J., Pang, W., Guo, Z. \& Chen, Z. (2017). Large-scale synthesis of ternary Sn5SbP3/C \\ composite by ball milling for superior stable sodium-ion battery anode. Electrochimica Acta, 235 107-113.
}




\section{Large-scale synthesis of ternary $\mathrm{Sn}_{5} \mathrm{SbP}_{3} / \mathrm{C}$ composite by ball milling for superior stable sodium-ion battery anode}

Wenchao Zhang, ${ }^{\mathrm{a}, \mathrm{b}}$ Jianfeng Mao, ${ }^{\text {,* }}$ Wei Kong Pang, ${ }^{\mathrm{b}, \mathrm{c}}$ Zaiping Guo ${ }^{\mathrm{b}}$, Zhixin Chen, ${ }^{\mathrm{a}, *}$

${ }^{\mathrm{a}}$ Engineering Materials Institute, School of Mechanical, Materials \& Mechatronics

Engineering, University of Wollongong, NSW 2500, Australia.

${ }^{\mathrm{b}}$ Institute for Superconducting \& Electronic Materials, University of Wollongong, Wollongong, NSW 2522, Australia.

${ }^{c}$ Australian Centre for Neutron Scattering, Australian Nuclear Science and Technology Organization, Locked Bag 2001, Kirrawee DC, NSW 2232, Australia.

* Corresponding authors

Jianfeng Mao: E-mail: jmao@uow.edu.au, T: +61 24221 5225, F: +61 242215630

Zhixin Chen: E-mail: zchen@uow.edu.au, T: +61 24221 4932, F: +61 242215474 


\begin{abstract}
Alloy-based materials (i.e. Sn, Sb, P) are promising candidates for sodium-ion battery (SIB) anodes, but they suffer from capacity decay during charge/discharge cycling due to the pulverization caused by their huge volume change. Nanostructures can slow down the capacity fade, but most of the synthesis methods of such nanostructured anodes are difficult to scale-up. Herein, a ternary $\mathrm{Sn}_{5} \mathrm{SbP}_{3} / \mathrm{C}$ composite was fabricated by a green, low cost, onestep and easily scalable ball-milling of elementary $\mathrm{Sn}, \mathrm{Sb}, \mathrm{P}$, and $\mathrm{C}$. The microstructure of the ball-milled powders consists of micrometric agglomerates of active nano $\mathrm{Sn}_{4} \mathrm{P}_{3}$ and $\mathrm{SnSb}$ and Sn particles. Carbon in the composite acts as a conducting matrix, and it does not only benefit to the ball milling efficiency, but also benefit to the cycle life of the electrode. Each of the active $\mathrm{Sn}_{4} \mathrm{P}_{3}$ and $\mathrm{SnSb}$ and $\mathrm{Sn}$ phases in the composite functions mutually as a buffer for the others. As a result, this ternary composite anode delivers a good capacity of $352.2 \mathrm{~mA} \mathrm{~h} \mathrm{~g}^{-1}$ at the current density of $2 \mathrm{~A} \mathrm{~g}^{-1}$, which is notably higher than that of the binary $\mathrm{Sn}_{4} \mathrm{P}_{3} / \mathrm{C}$ and $\mathrm{SnSb} / \mathrm{C}$ composites produced under the same conditions.
\end{abstract}

Key words: Sodium-ion battery, alloy anode, low cost, large-scale 


\section{Introduction}

Sodium-ion batteries (SIBs) have been attracting great interest recently due to the low cost and abundance of sodium resources, especially for applications in stationary energy storage.[1-16] The successful commercialization of SIBs does not only calls for the development of electrode materials with enhanced performance, but also scalable synthesis protocols.[17] Alloy-based materials are believed to be very promising candidates for SIB anodes due to their high gravimetric and volumetric capacities, and slightly higher thermodynamic potential. [1, 18, 19] For instance, group $14\left(\mathrm{Sn}, \mathrm{Na}_{15} \mathrm{Sn}_{4}, 847 \mathrm{~mA} \mathrm{~h} \mathrm{~g}^{-1}\right)$ and 15 elements (P, Na 3 P, $2596 \mathrm{~mA} \mathrm{~h} \mathrm{~g}^{-1}$; Sb, Na $\mathrm{Sb}, 660 \mathrm{~mA} \mathrm{~h} \mathrm{~g}^{-1}$ ) based alloys[14, 20, 21] have been intensively studied recently and have showed promising properties. Nevertheless, large volume changes (>200\%) are inevitable for these alloy anodes during sodiation/desodiation. The huge volume expansion will lead to continuous pulverization, particle cracking, and subsequent separation of the active materials from the current collector and result in fast capacity fade.[1, 2, 22]

Nanomaterials with designed and optimized structures can slow down the capacity fade. The use of these nanosized materials by industry in the near future is unlikely, however, because of their complicated synthesis procedures, very high synthesis costs, high surface reactivity, low tap density, and difficulties for large-scale synthesis. In contrast, ball milling is a simple, cheap, and easily scalable synthesis method, and hence, it has a potential for industrial-scale application. Binary composite systems such as $\mathrm{Sn}_{4} \mathrm{P}_{3}$ and $\mathrm{SnSb}$ formed via ball milling have been shown to have significantly better electrochemical performance over pristine $\mathrm{Sn}, \mathrm{Sb}$, or $\mathrm{P}^{20-3}$ The electrochemical performance of the ball milled binary $\mathrm{Sn}_{4} \mathrm{P}_{3}$ or SnSb is still far from adequate for practical applications, however, especially in terms of high rate 
charging/discharging.[23-26]

Herein, we report a ternary $\mathrm{Sn}_{5} \mathrm{SbP}_{3} / \mathrm{C}$ composite synthesized via ball-milling, which contains $\mathrm{Sn}_{4} \mathrm{P}_{3}, \mathrm{SnSb}$ and $\mathrm{Sn}$ nanoparticles (NPs), which are in intimate contact with each other and form heterojunctions in a conductive carbon matrix. The ternary composite displays superior electrochemical performance to the binary $\mathrm{Sn}_{4} \mathrm{P}_{3} / \mathrm{C}$ or $\mathrm{SnSb} / \mathrm{C}$ composite. It was found that the $\mathrm{Sn}$ and $\mathrm{SnSb}$ in the composite facilitate the electron transfer and $\mathrm{Sn}_{4} \mathrm{P}_{3}$ provides high sodium storage capacity. The $\mathrm{SnSb}$ phase also promotes a superior stable cycling performance by the formation of an intermediate amorphous phase $\mathrm{Na}_{\mathrm{x}} \mathrm{Sb}$.[23, 27-29] It seems that the superior electrochemical performance of the ternary $\mathrm{Sn}_{5} \mathrm{SbP}_{3} / \mathrm{C}$ composite is resulted from a synergetic effect of the multi phased nanostructure on a conductive network. Importantly ball milling is a scalable process and a large volume of composite architecture electrodes can be easily produced for practical applications.

\section{Experimental Section}

\section{Preparation of $\mathrm{Sn}_{5} \mathrm{SbP}_{3} / \mathrm{C}$ ternary composite}

$\mathrm{Sn}_{5} \mathrm{SbP}_{3} / \mathrm{C}$ powder was directly synthesized by ball milling the raw materials of $\mathrm{Sn}$ (Aldrich, $\geq 99.8 \%$ ), Sb (Aldrich, $\geq 99.5 \%$ ), red phosphorus (Aldrich, $\geq 99 \%$ ) and carbon black. The weight ratio of $\mathrm{Sn}: \mathrm{Sb}: \mathrm{P}: \mathrm{C}$ in the composite is $64.26: 13.18: 10.06: 12.5$. The ball milling was conducted in a planetary QM-1SP2 ball mill for $30 \mathrm{~h}$ at $500 \mathrm{rpm}$. A stainless steel jar and stainless steel balls of $10 \mathrm{~mm}$ in diameter are used. The powder-to-ball weight ratio was 1:30. For comparison, binary composites $\mathrm{SnSb} / \mathrm{C}$ and $\mathrm{Sn}_{4} \mathrm{P}_{3} / \mathrm{C}$ were also synthesized under the same conditions. The weight ratios are $\mathrm{Sn}: \mathrm{Sb}: \mathrm{C}=43.19: 44.31: 12.5$ and $\mathrm{Sn}: \mathrm{P}: \mathrm{C}=73.11$ : 14.39: 12.5 in the binary composites $\mathrm{SnSb} / \mathrm{C}$ and $\mathrm{Sn}_{4} \mathrm{P}_{3} / \mathrm{C}$ respectively. The storage and handling of all the samples were performed in an Ar filled glovebox (MBraun Unilab).

\section{Materials characterization}

The phasic composition and information of the as-prepared powders were characterized by 
powder X-ray diffraction (XRD) on a GBC MMA diffractometer with a $\mathrm{Cu} \mathrm{K}_{\alpha}$ radiation at a scanning rate of $1^{\circ} \mathrm{min}^{-1}$. The particle morphology and size of the prepared powder materials were characterized on a JEOL JSM-7500FA field-emission scanning electron microscope (FESEM) and on a JEOL ARM-200F cold field emission and aberration-corrected transmission electron microscope (TEM).

\section{Electrochemical measurements}

Electrodes were fabricated using a slurry-coating method. The synthesized materials $\left(\mathrm{Sn}_{5} \mathrm{SbP}_{3} / \mathrm{C}, \mathrm{Sn}_{4} \mathrm{P}_{3} / \mathrm{C}\right.$ and $\left.\mathrm{SnSb} / \mathrm{C}\right)$ were mixed with Super P carbon black and carboxymethyl cellulose (CMC) in the weight ratio of 8:1:1 to form slurry with deionized (DI) water. Then, the slurry was coated on copper foil and dried in a vacuum oven at $80{ }^{\circ} \mathrm{C}$ for $12 \mathrm{~h}$. Coin-type (CR2032) cells were assembled in an argon-filled glove box $\left(\mathrm{H}_{2} \mathrm{O}<0.1 \mathrm{ppm}, \mathrm{O}_{2}<0.1 \mathrm{ppm}\right)$, with $1 \mathrm{M} \mathrm{NaClO}_{4}$ in a mixture of propylene carbonate (PC) with 5 wt. \% fluoroethylene carbonate (FEC) as the electrolyte. Cyclic voltammetry (CV) tests were conducted on a Biologic VMP-3 electrochemical workstation at a scan rate of $0.05 \mathrm{mV} \mathrm{s}^{-1}$. The cells were galvanostatically charged-discharged between 0.01 and $2.0 \mathrm{~V}$ versus $\mathrm{Na} / \mathrm{Na}^{+}$at various current densities on a Land battery tester. The mass loading of active material $\left(\mathrm{Sn}_{5} \mathrm{SbP}_{3}\right.$, $\mathrm{Sn}_{4} \mathrm{P}_{3}$ and $\mathrm{SnSb}$ ) was over $0.78 \mathrm{mg} \mathrm{cm}^{-2}$. The specific capacity was calculated based on the weight of pure $\mathrm{Sn}_{5} \mathrm{SbP}_{3}, \mathrm{Sn}_{4} \mathrm{P}_{3}$ and $\mathrm{SnSb}$ active materials.

\section{Results and discussion}

Fig. 1a presents the X-ray diffraction (XRD) patterns of the ternary $\mathrm{Sn}_{5} \mathrm{SbP}_{3} / \mathrm{C}$ and the binary $\mathrm{Sn}_{4} \mathrm{P}_{3} / \mathrm{C}$ and $\mathrm{SnSb} / \mathrm{C}$ composites. The ternary $\mathrm{Sn}_{5} \mathrm{SbP}_{3} / \mathrm{C}$ composite contains three intermetallic and metallic phases: $\mathrm{Sn}_{4} \mathrm{P}_{3}$ (ICSD\#15014), $\mathrm{SnSb}$ (ICSD\#52303) and $\mathrm{Sn}$ (ICSD\#40037). In contrast, only $\mathrm{Sn}_{4} \mathrm{P}_{3}$ or $\mathrm{SnSb}$ was observed in the binary composite $\mathrm{Sn}_{4} \mathrm{P}_{3} / \mathrm{C}$ or $\mathrm{SnSb} / \mathrm{C}$, respectively. The carbon black is not observed in the XRD patterns due to 
its amorphous features, but it can be clearly identified by Raman analysis, as shown in Fig. $\mathrm{S} 1$ in the Supporting Information. Also, no bonds of $\mathrm{C}$ with $\mathrm{Sn}, \mathrm{Sb}$, and/or $\mathrm{P}$ are observed in X-ray photoelectron spectroscopy (XPS) analysis (Fig. S2). Fig. 1b presents the a Rietveld refinement profile for the $\mathrm{Sn}_{5} \mathrm{SbP}_{3} / \mathrm{C}$ composite, performed by using the GSAS-II software package.[30] All the peaks in the XRD pattern of the ternary $\mathrm{Sn}_{5} \mathrm{SbP}_{3} / \mathrm{C}$ can be indexed those of hexagonal $\mathrm{Sn}_{4} \mathrm{P}_{3}(\mathrm{R} \overline{3} \mathrm{~m})$, cubic $\mathrm{SnSb}(\mathrm{F} \mathrm{m} \overline{3} \mathrm{~m})$, and tetragonal $\mathrm{Sn}$ (I4//amd). The lattice parameters obtained from the Rietveld refinement are $a=4.0283 \AA, c=35.6999 \AA$ for the $\mathrm{Sn}_{4} \mathrm{P}_{3}, a=6.1278 \AA$ for the SnSb and $a=5.8456 \AA c=3.1903 \AA$ for the Sn respectively. The amount of each phase in the $\mathrm{Sn}_{5} \mathrm{SbP}_{3}$ was calculated as $65.75 \pm 3.14 \mathrm{wt} \% \mathrm{Sn}_{4} \mathrm{P}_{3}, 18.54 \pm 0.62$ $\mathrm{wt} \% \mathrm{SnSb}$, and $15.71 \pm 0.67 \mathrm{wt} \% \mathrm{Sn}$.
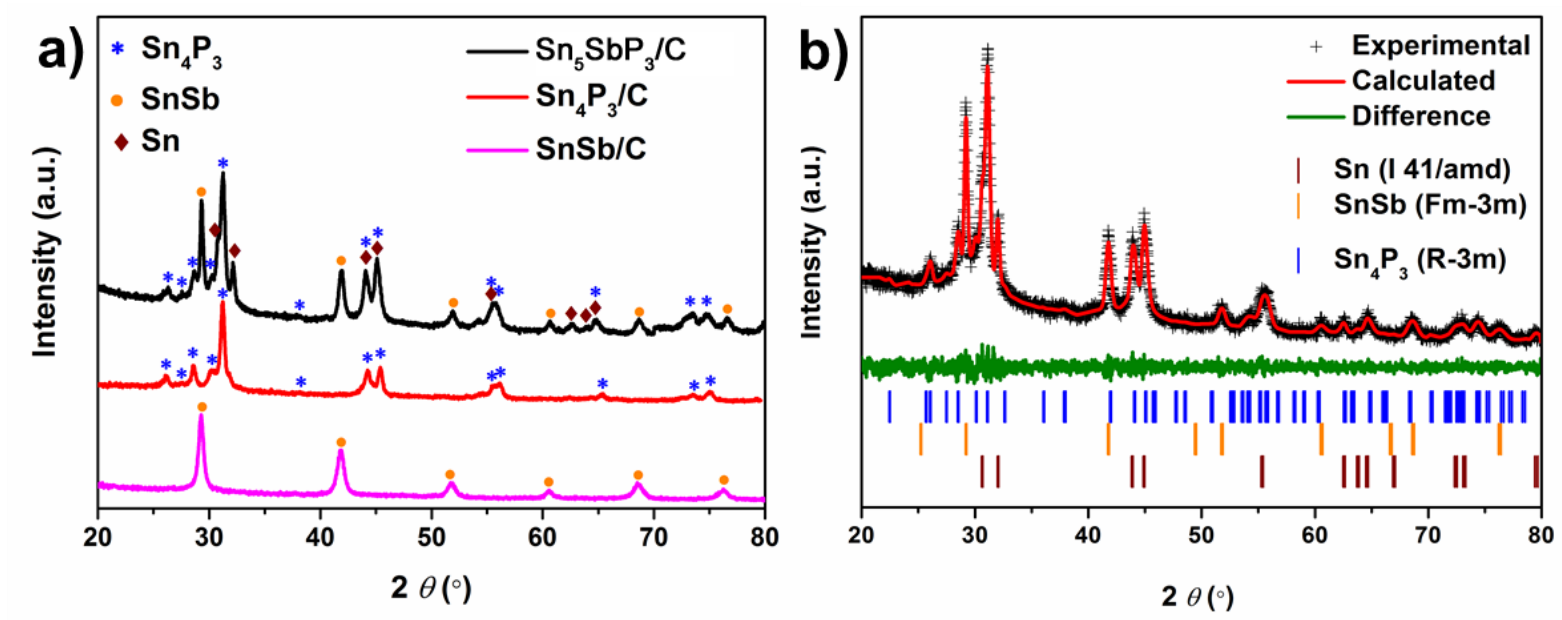

Fig.1. a) XRD patterns of $\mathrm{Sn}_{5} \mathrm{SbP}_{3} / \mathrm{C}$ composite, $\mathrm{Sn}_{4} \mathrm{P}_{3} / \mathrm{C}$ and $\mathrm{SnSb} / \mathrm{C}$; b) Rietveld refinement profile for the $\mathrm{Sn}_{5} \mathrm{SbP}_{3} / \mathrm{C}$ composite.

The as-milled $\mathrm{Sn}_{5} \mathrm{SbP}_{3} / \mathrm{C}, \mathrm{Sn}_{4} \mathrm{P}_{3} / \mathrm{C}$ and $\mathrm{SnSb} / \mathrm{C}$ powders were characterized by $\mathrm{SEM}$ and the results are shown in Fig 2. It can be seen that the powders in all three samples show irregular shapes in their morphology. The agglomerated and micro sized particles are the main constituent of the powders, and there are also numerous primary nanoparticles about $50 \mathrm{~nm}$ $100 \mathrm{~nm}$ in size (Figs. 2a, b, c). The mixed structure of the micro- and nano- particles may allow full contact of the electrolyte with the active materials and hence facilitate an efficient 
ion transportation.[31] It can also be seen that $\mathrm{Sn}, \mathrm{Sb}$, and $\mathrm{P}$ are distributed uniformly in the $\mathrm{Sn}_{5} \mathrm{SbP}_{3} / \mathrm{C}$ composite according to the energy dispersive $\mathrm{X}$-ray spectroscopy (EDX) (Fig. 2d). EDX results for the $\mathrm{Sn}_{4} \mathrm{P}_{3} / \mathrm{C}$ and $\mathrm{SnSb} / \mathrm{C}$ are shown in Fig. $\mathrm{S} 3$ and the compositions of the three different powders are listed in Table S1.
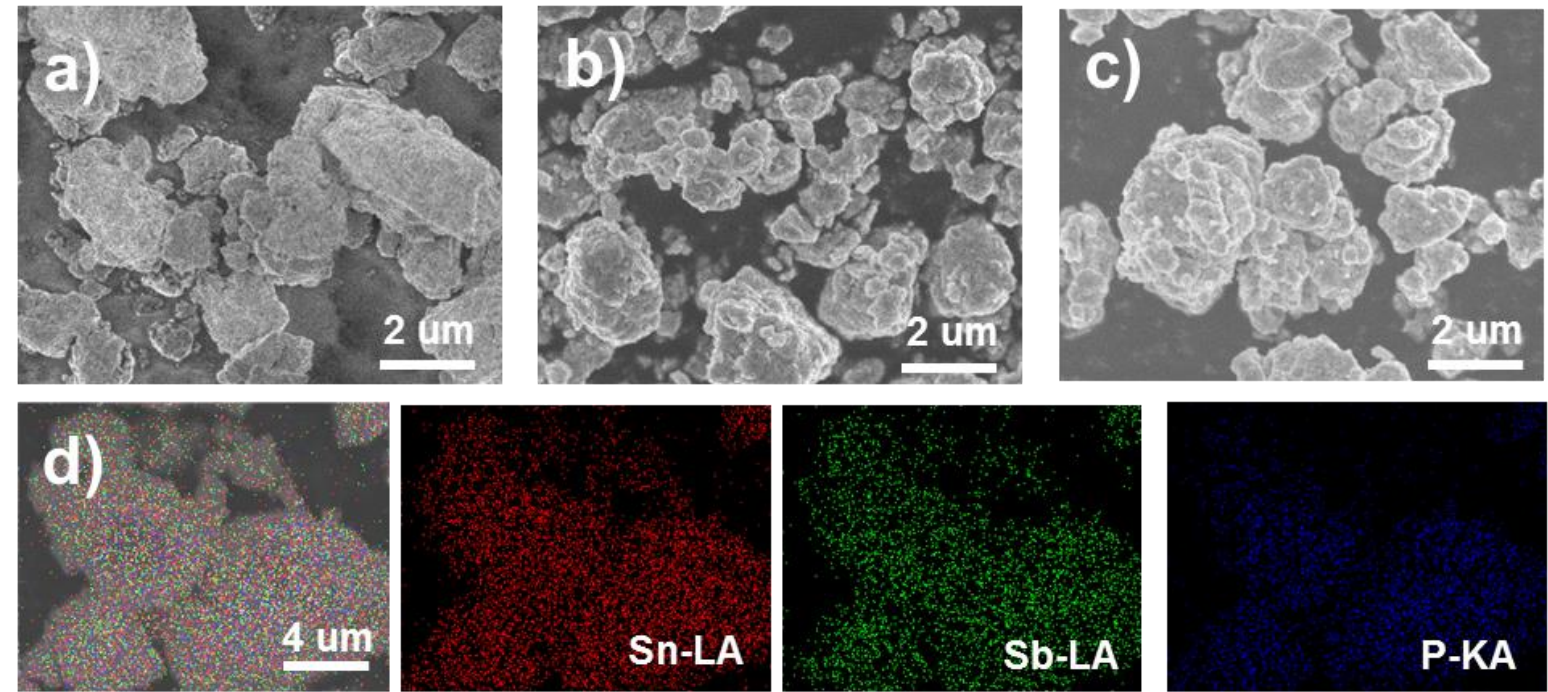

Fig.2. $\mathrm{SEM}$ images of a) $\mathrm{Sn}_{5} \mathrm{SbP}_{3} / \mathrm{C}$ composite, b) $\mathrm{Sn}_{4} \mathrm{P}_{3} / \mathrm{C}$, c) $\mathrm{SnSb} / \mathrm{C}$ powders; d) EDX mappings of $\mathrm{Sn}_{5} \mathrm{SbP}_{3} / \mathrm{C}$ composite.

Fig. 3 shows a TEM image, and a HRTEM image taken from a micron particle of the $\mathrm{Sn}_{5} \mathrm{SbP}_{3} / \mathrm{C}$ composite. The micron particle is composed of nanoparticles with the size ranging from 20 to $100 \mathrm{~nm}$ (Fig. 3a). These nanoparticles are composed of $\mathrm{Sn}_{4} \mathrm{P}_{3}, \mathrm{SnSb}$ and $\mathrm{Sn}$ and they are intimately mixed and uniformly distributed in the amorphous carbon matrix (Fig. 3b). The microscale particle size could make the power easy to handle and a higher tapped density, while the nanostructure provides short and fast ion diffusion path during sodiation and desodiation cycling. Figure $3 \mathrm{~b}$ shows a HRTEM image of such a nanoparticle and the inset shows the indexed fast Fourier transform (FFT) pattern. From this pattern the lattice fringes were indexed and the spacings of the fringes were measured to be about $0.283 \mathrm{~nm}$ for the $(107)$ planes and $0.309 \mathrm{~nm}$ for the $(01 \overline{5})$ planes. These values are in good agreement with the $d_{107}$ and $d_{01} \overline{5}$ of $\mathrm{Sn}_{4} \mathrm{P}_{3}$. The $\mathrm{Sn}_{4} \mathrm{P}_{3}$ particle is about $20 \mathrm{~nm}$ in size and is also 
surrounded by a few minor Sn and SnSb particles. The HRTEM observations are consistent with the XRD results and further confirm the coexistence of the three phases: $\mathrm{Sn}_{4} \mathrm{P}_{3}, \mathrm{SnSb}$ and $\mathrm{Sn}$ in the $\mathrm{Sn}_{5} \mathrm{SbP}_{3}$. It also should be noted that the phosphorus containing phase is sensitive to the electron beam and unstable at high voltages and at room temperature. Therefore, the lowest available voltage of $80 \mathrm{kV}$ and a liquid nitrogen holder were used during the HRTEM measurements.
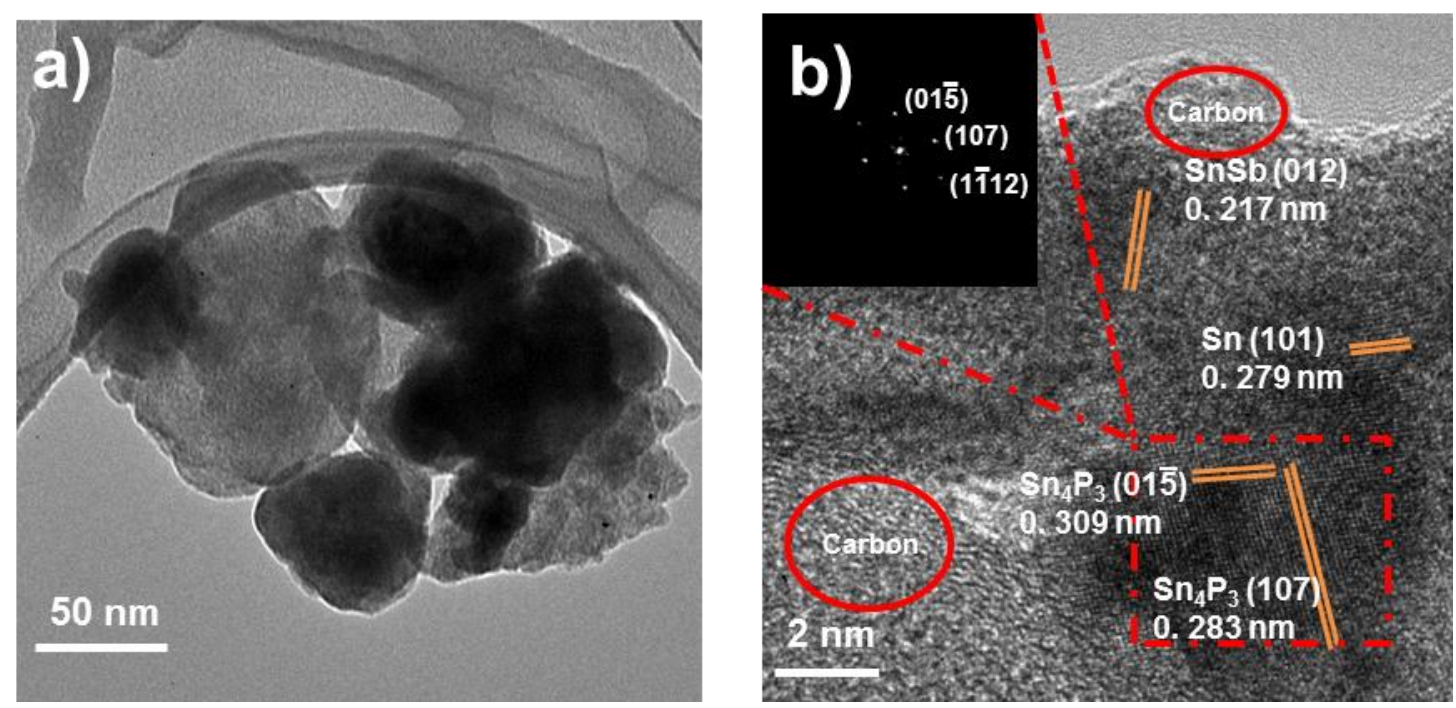

Fig. 3. a) TEM image of the $\mathrm{Sn}_{5} \mathrm{SbP}_{3} / \mathrm{C}$ composite, b) HRTEM image of the $\mathrm{Sn}_{5} \mathrm{SbP}_{3} / \mathrm{C}$ composite, with the inset showing the FFT pattern of the zone outlined in red.

The electrochemical performance in terms of sodium storage of the $\mathrm{Sn}_{5} \mathrm{SbP}_{3} / \mathrm{C}$ composite was systematically investigated. Fig. 4a displays cyclic voltammograms (CV) of the $\mathrm{Sn}_{5} \mathrm{SbP}_{3} / \mathrm{C}$ composite. During the first cathodic scan, a weak peak occurred at around $0.8 \mathrm{~V}$, but it reduced slowly and disappeared in the following four cycles. This peak reduction may be attributed to the sodiation of amorphous phosphorus at the surface of the $\mathrm{Sn}_{5} \mathrm{SbP}_{3} / \mathrm{C}$ composite. The apparent reduction band at around 0.01-0.1 V may be attributed to the formation of $\mathrm{Na}_{15} \mathrm{Sn}_{4}$ and $\mathrm{Na}_{3} \mathrm{P}, \mathrm{Na}_{3} \mathrm{Sb}$ (Eq. 1). In the second and subsequent cathodic scans, this large reduction band has obviously shrunken and another new reduction peak appeared at around $0.2-0.7 \mathrm{~V}$. These two reduction bands at $0.18-0.69 \mathrm{~V}$ and $0.01-0.16 \mathrm{~V}$ can be attributed 
to the $\mathrm{Na}-\mathrm{Sn}, \mathrm{Na}-\mathrm{Sb}$ and $\mathrm{Na}-\mathrm{P}$ alloying reactions (Eqs. 2, 3 and 4), according to the $\mathrm{CV}$ results for the $\mathrm{Sn}_{4} \mathrm{P}_{3} / \mathrm{C}$ and $\mathrm{SnSb} / \mathrm{C}$ electrodes (Figs. S4a and b). During the anodic scans, the oxidation peaks at around 0.29 and $0.8 \mathrm{~V}$ are mainly attributed to the $\mathrm{Na}-\mathrm{Sn}$ and $\mathrm{Na}-\mathrm{P}$ dealloying reactions (Eqs. 3 and 4), and the Na-Sn and Na-Sb de-alloying reactions (Eqs. 2 and 4), respectively. The main peak at around $0.6 \mathrm{~V}$ is due to the desodiation of $\mathrm{Na}_{3} \mathrm{P}$, although some overlap of the Na-Sn and Na-Sb de-alloying reactions may also be present. Therefore, it is likely that the sodiation and desodiation mechanism may proceed as follows:

During the initial charging ( $\mathrm{Na}$ insertion) process

$$
\mathrm{Sn}_{4} \mathrm{P}_{3}+\mathrm{SnSb}+\mathrm{Sn}+34.5 \mathrm{Na}^{+}+34.5 e^{-} \rightarrow 1.5 \mathrm{Na}_{15} \mathrm{Sn}_{4}+3 \mathrm{Na}_{3} \mathrm{P}+\mathrm{Na}_{3} \mathrm{Sb}
$$

In the subsequent discharging (sodiation) and charging (desodiation) processes

$$
\begin{aligned}
S b+3 N a^{+}+3 e^{-} & \leftrightarrow N a_{3} S b \\
P+3 N a^{+}+3 e^{-} & \leftrightarrow N a_{3} P \\
S n+3.75 N a^{+}+3.75 e^{-} & \leftrightarrow N a_{3.75} S n
\end{aligned}
$$

The theoretical capacity of $\mathrm{Sn}_{5} \mathrm{SbP}_{3}, \mathrm{Sn}_{4} \mathrm{P}_{3}$ and $\mathrm{SnSb}$ could be calculated as 996.3, 1130.5 and $753.8 \mathrm{~mA} \mathrm{~h} \mathrm{~g}^{-1}$, respectively. Fig. $4 \mathrm{~b}$ shows the rate performance of the three electrodes $\left(\mathrm{Sn}_{5} \mathrm{SbP}_{3} / \mathrm{C}, \mathrm{Sn}_{4} \mathrm{P}_{3} / \mathrm{C}\right.$ and $\left.\mathrm{SnSb} / \mathrm{C}\right)$ at current densities of $100,250,500,1000$ and $2000 \mathrm{~mA} \mathrm{~g}^{-}$ 1. Clearly, the rate performance of the $\mathrm{Sn}_{5} \mathrm{SbP}_{3} / \mathrm{C}$ is better than that of those $\mathrm{Sn}_{4} \mathrm{P}_{3} / \mathrm{C}$ or $\mathrm{SnSb} / \mathrm{C}$. Moreover, it seems that the superior sodium storage performance of the ternary composite to the binary composites becomes even more outstanding at the higher current densities. For example, a capacity of $352.2 \mathrm{~mA} \mathrm{~h} \mathrm{~g}^{-1}$ is obtained for the $\mathrm{Sn}_{5} \mathrm{SbP}_{3} / \mathrm{C}$ at the current density of $2 \mathrm{~A} \mathrm{~g}^{-1}$, which is much larger than those of the two binary composite at the same current density. The capacity retention ratio of the $\mathrm{Sn}_{5} \mathrm{SbP}_{3} / \mathrm{C}$ composite electrode is $57.9 \%$ which is also higher than $42.02 \%$ of the $\mathrm{Sn}_{4} \mathrm{P}_{3} / \mathrm{C}$ and $48.96 \%$ of the $\mathrm{SnSb} / \mathrm{C}$ at the same current density of $2 \mathrm{Ag}^{-1}$, as shown in Fig. 4c.

To better understand the reasons for the superior performance of the $\mathrm{Sn}_{5} \mathrm{SbP}_{3} / \mathrm{C}$ electrode, electrochemical impedance spectroscopy (EIS) was also conducted on the three electrodes 
and compared, as shown in Fig. 4d. The EIS curves contain a depressed semicircle in the high frequency region, and a straight sloping line in the low frequency region. The resistor $\mathrm{R}_{\mathrm{ct}}$ in parallel with the constant phase element $(\mathrm{CPE})$ in the equivalent circuit is the charge-transfer resistance at the electrode/electrolyte interface, which is calculated from the depressed semicircle. Clearly, the $\mathrm{R}_{\mathrm{ct}}$ of the $\mathrm{Sn}_{5} \mathrm{SbP}_{3} / \mathrm{C}$ electrode $(110 \Omega)$ is much lower than those of the binary electrodes ( $468 \Omega$ for $\mathrm{Sn}_{4} \mathrm{P}_{3} / \mathrm{C}$ and $1439 \Omega$ for $\mathrm{SnSb} / \mathrm{C}$ ). The lower the $\mathrm{R}_{\mathrm{ct}}$ value is, the faster the ion transportation. Thus, the $\mathrm{Sn}_{5} \mathrm{SbP}_{3} / \mathrm{C}$ electrode has the fastest reaction kinetics among the three electrodes.
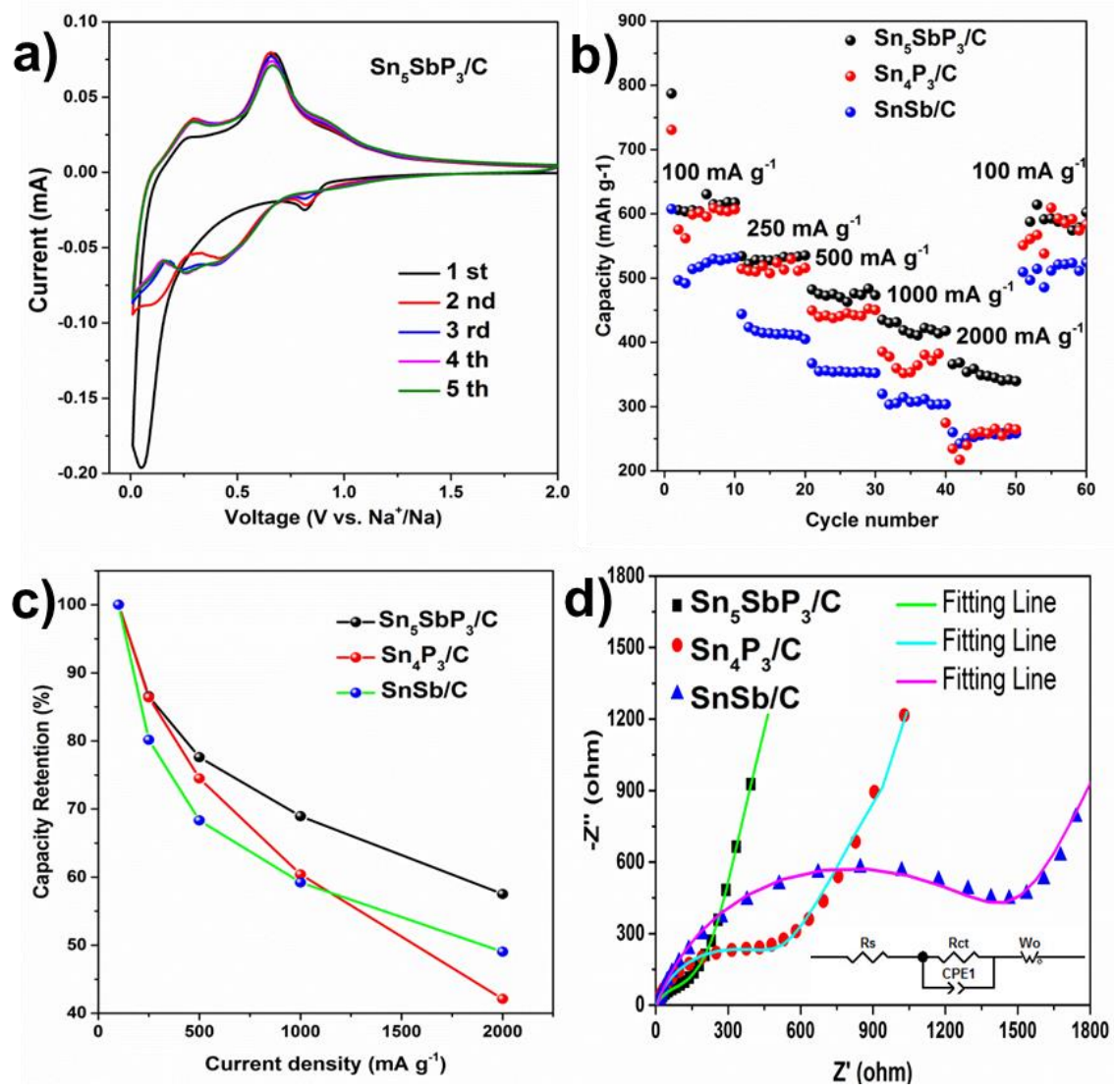

Fig. 4. (a) Cyclic voltammograms (CVs) of $\mathrm{Sn}_{5} \mathrm{SbP}_{3} / \mathrm{C}$ composite for the first 5 cycles, tested at a scanning rate of $0.05 \mathrm{mV} \mathrm{s}^{-1}, \mathrm{~b}$ ) rate performance of the three electrodes at current densities from $100 \mathrm{~mA} \mathrm{~g}^{-1}$ to $2000 \mathrm{~mA} \mathrm{~g}^{-1}, \mathrm{c}$ ) average discharge capacity retention for the 3 electrodes at current densities from $100 \mathrm{~mA} \mathrm{~g}^{-1}$ to $2000 \mathrm{~mA} \mathrm{~g}^{-1}$, and d) EIS spectra of the three electrodes. 
To further explore the superior electrochemical performance of the $\mathrm{Sn}_{5} \mathrm{SbP}_{3} / \mathrm{C}$ composite, the long-term cycling stability of the three samples was investigated and compared, as shown in Fig. 5. The $\mathrm{Sn}_{5} \mathrm{SbP}_{3} / \mathrm{C}$ electrode exhibits a relatively more stable cycling performance at 500 $\mathrm{mA} \mathrm{g}^{-1}$ (Fig 5a). A capacity of $431.6 \mathrm{~mA} \mathrm{~h} \mathrm{~g}^{-1}$ is delivered by the $\mathrm{Sn}_{5} \mathrm{SbP}_{3} / \mathrm{C}$ after the 200 cycles, which is higher than $346.4 \mathrm{~mA} \mathrm{~h} \mathrm{~g}^{-1}$ of the $\mathrm{Sn}_{4} \mathrm{P}_{3} / \mathrm{C}$ and $269.5 \mathrm{~mA} \mathrm{~h} \mathrm{~g}{ }^{-1}$ of the $\mathrm{SnSb} / \mathrm{C}$ after the same number of cycles. Meanwhile, the retention rates with respect to their second cycle capacities are $77.65 \%$ and $69.74 \%$, for the $\mathrm{Sn}_{4} \mathrm{P}_{3} / \mathrm{C}$ and $\mathrm{SnSb} / \mathrm{C}$ respectively and they are much lower than that of $\mathrm{Sn}_{5} \mathrm{SbP}_{3} / \mathrm{C}$ electrode (95.2\% of the second cycle capacity). Accordingly, the discharge-charge profiles of the three electrodes at the current density of 500 $\mathrm{mA} \mathrm{g}^{-1}$ at the $1^{\text {st }}, 2^{\text {nd }}, 50^{\text {th }}, 100^{\text {th }}$ and $200^{\text {th }}$ cycles are presented in Figs. $5 \mathrm{~b}-\mathrm{d}$, respectively. The profiles display a long plateau at around 0.01-0.3 $\mathrm{V}\left(\mathrm{Sn}_{5} \mathrm{SbP}_{3} / \mathrm{C}\right), 0.01-0.5 \mathrm{~V}\left(\mathrm{Sn}_{4} \mathrm{P}_{3} / \mathrm{C}\right)$ and 0.2-0.3 V $(\mathrm{SnSb} / \mathrm{C})$, respectively, in their first discharge process. The plateaus are mainly due to the formation of the SEI layer. Several discharge and charge plateaus are observed after cycling, however. These results are in agreement with the CV results (Fig. 4a, Fig. S4a, b), and reflect the stepwise alloy phase transition reactions (Eqs. 2-4). The $\mathrm{Sn}_{5} \mathrm{SbP}_{3} / \mathrm{C}$ composite electrode also exhibits higher and more stable capacities than the binary composite electrodes at the higher current density $\left(1 \mathrm{~A} \mathrm{~g}^{-1}\right)$, as shown in Fig. $5 \mathrm{e}$. A capacity of $370.5 \mathrm{~mA} \mathrm{~h} \mathrm{~g}^{-1}$ is delivered by the $\mathrm{Sn}_{5} \mathrm{SbP}_{3} / \mathrm{C}$ composite in the $200^{\text {th }}$ cycle, which is higher than $251.5 \mathrm{~mA} \mathrm{~h} \mathrm{~g}^{-1}$ of the $\mathrm{Sn}_{4} \mathrm{P}_{3} / \mathrm{C}$ and $106 \mathrm{~mA} \mathrm{~h} \mathrm{~g}^{-1}$ of the $\mathrm{SnSb} / \mathrm{C}$ in the same number of cycles. 

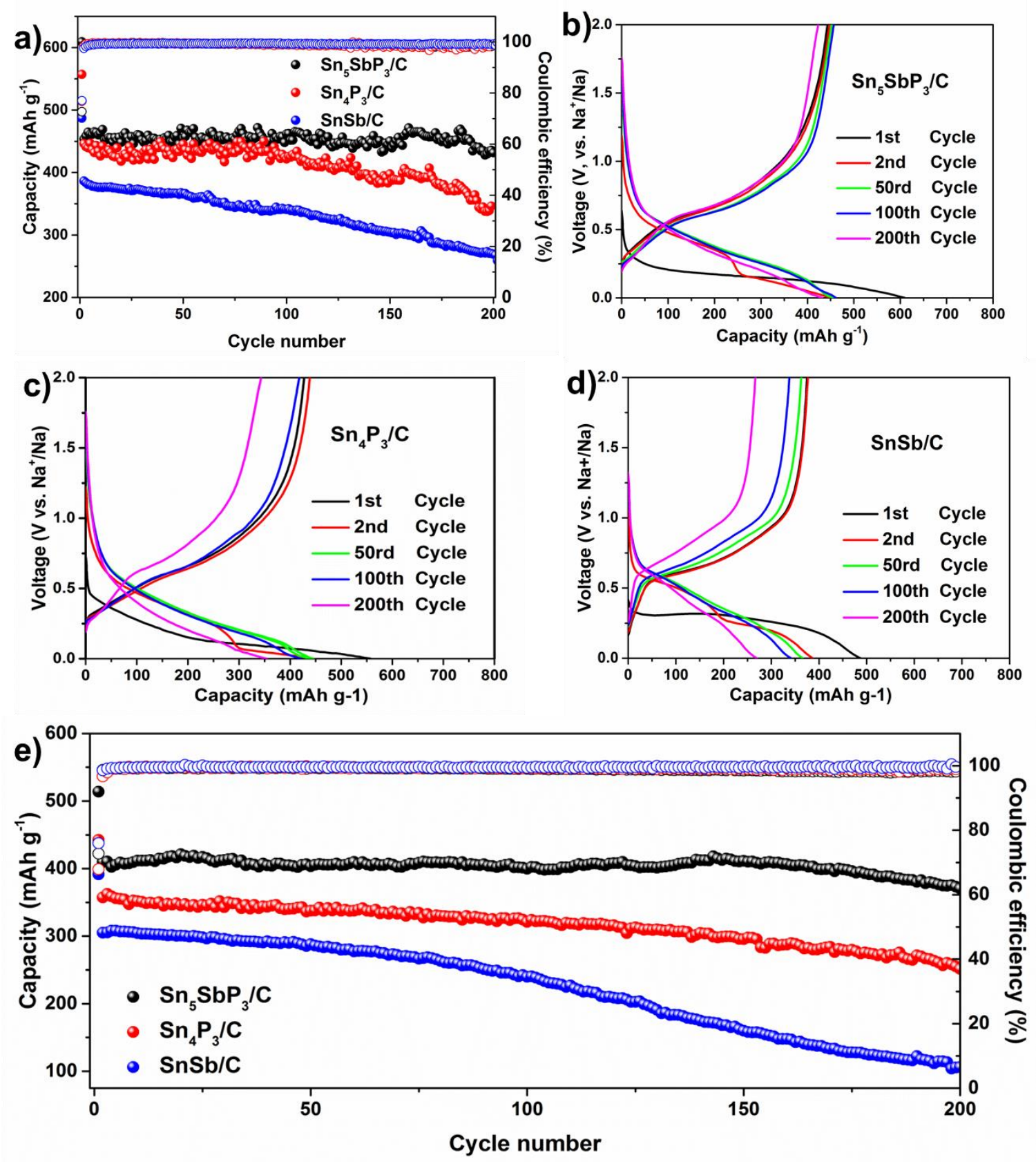

Fig. 5. (a) Cycling performance and Coulombic efficiency of three different materials tested at a current density of $500 \mathrm{~mA} \mathrm{~g}^{-1}$ in the range of $0.01-2 \mathrm{~V}\left(\mathrm{vs} . \mathrm{Na}^{+} / \mathrm{Na}\right)$. Galvanostatic chargedischarge curves of (b) $\mathrm{Sn}_{5} \mathrm{SbP}_{3} / \mathrm{C}$ composite, (c) $\mathrm{Sn}_{4} \mathrm{P}_{3} / \mathrm{C}$ and (d) $\mathrm{SnSb} / \mathrm{C}$ for the $1^{\text {st }}, 2^{\text {nd }}, 50^{\text {th }}$, $100^{\text {th }}$ and $200^{\text {th }}$ cycles tested at current density of $500 \mathrm{~mA} \mathrm{~g}^{-1}$ in the range of $0.01-2 \mathrm{~V}$ (vs. $\mathrm{Na}^{+} / \mathrm{Na}$ ) (e) Cycling performance and Coulombic efficiency of $\mathrm{Sn}_{5} \mathrm{SbP}_{3} / \mathrm{C}, \mathrm{Sn}_{4} \mathrm{P}_{3} / \mathrm{C}$ and $\mathrm{SnSb} / \mathrm{C}$ tested at a current density of $1000 \mathrm{~mA} \mathrm{~g}^{-1}$ in the range of $0.01-2 \mathrm{~V}\left(\mathrm{vs} . \mathrm{Na}^{+} / \mathrm{Na}\right)$. It is well known that one of the deadly problems for alloy-based anodes in SIBs is the huge 
volume expansion during charging/discharging, which leads to continuous pulverization upon cycling $[32,33]$ Therefore, the morphology changes before and after 100 cycles were examined by SEM, as shown in Figs. 6 a $-\mathrm{f}$. The $\mathrm{Sn}_{5} \mathrm{SbP}_{3} / \mathrm{C}$ composite electrode shows no obvious morphological change and only a few micro cracks were observed after 100 cycles. The $\mathrm{Sn}_{4} \mathrm{P}_{3} / \mathrm{C}$ and $\mathrm{SnSb} / \mathrm{C}$ electrodes, however, show not only more cracks, but these cracks are also much coarser. Some of the cracks can be as wide as $5 \mu \mathrm{m}$ and hundreds of micrometers long after 100 cycles. The results indicate that the volume changes are alleviated effectively in the ternary composite, and hence, it has the superior electrochemical performance.
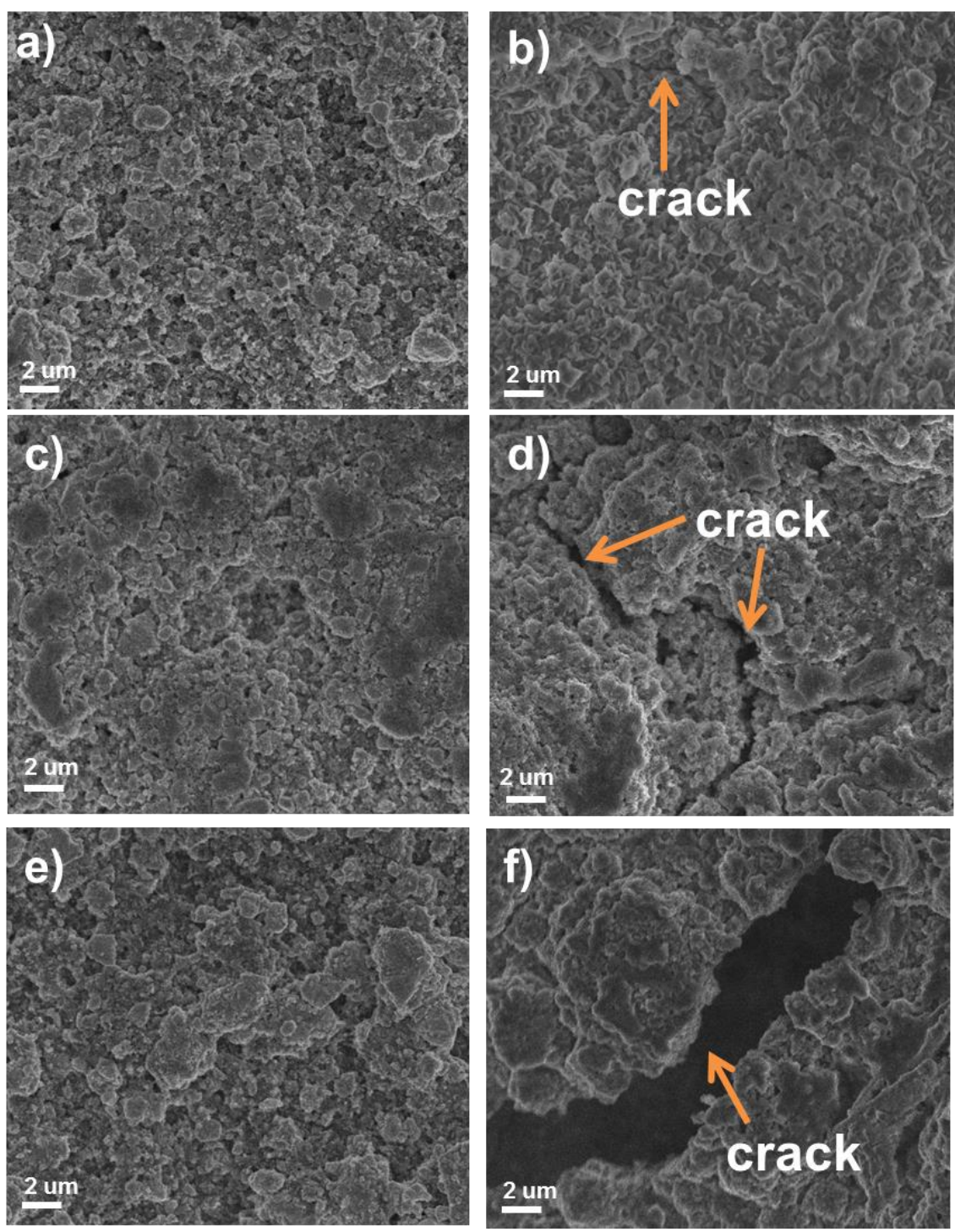

Fig. 6. FESEM image of a) fresh $\mathrm{Sn}_{5} \mathrm{SbP}_{3} / \mathrm{C}$ electrode, b) $\mathrm{Sn}_{5} \mathrm{SbP}_{3} / \mathrm{C}$ composite after 100 
cycles at $1000 \mathrm{~mA} \mathrm{~g}^{-1}$, c) fresh $\mathrm{Sn}_{4} \mathrm{P}_{3} / \mathrm{C}$ electrode, d) $\mathrm{Sn}_{4} \mathrm{P}_{3} / \mathrm{C}$ composite after 100 cycles at $1000 \mathrm{~mA} \mathrm{~g}^{-1}$, e) fresh $\mathrm{SnSb} / \mathrm{C}$ electrode, and f) $\mathrm{SnSb} / \mathrm{C}$ composite after 100 cycles at 1000

$$
\mathrm{mA} \mathrm{g}^{-1}
$$

The superior electrochemical performance of the ternary $\mathrm{Sn}_{5} \mathrm{SbP}_{3} / \mathrm{C}$ composite can be attributed to its unique structure, where the $\mathrm{Sn}_{4} \mathrm{P}_{3}, \mathrm{SnSb}$ and $\mathrm{Sn}$ nanoparticles (NPs) are in intimate contact with each other and form heterojunctions in the conductive carbon matrix. The three phases may play different and complemental roles in the ternary $\mathrm{Sn}_{5} \mathrm{SbP}_{3} / \mathrm{C}$ composite electrode because that the $\mathrm{Sn}_{4} \mathrm{P}_{3}$ phase has a high capacity but a very low electrical conductivity, the Sn and SnSb should have good electric conductivity. (Table S2). Therefore the $\mathrm{Sn}$ and $\mathrm{SnSb}$ phases together with the conductive carbon matrix could form continuous conductive networks for faster diffusion of electrons[23] which in turn improves the electrochemical performance of the $\mathrm{Sn}_{4} \mathrm{P}_{3}$. The $\mathrm{Sn}_{4} \mathrm{P}_{3}$ and $\mathrm{SnSb}$ have different reaction potentials according to the CV results (Fig. 4a and S4). Therefore it is expected that the reaction products of $\mathrm{Na}_{x} \mathrm{Sn}, \mathrm{Na}_{y} \mathrm{Sb}$ and $\mathrm{Na}_{z} \mathrm{P}$ in the ternary composite electrode would act as buffers to support each other and moderate the volume expansion during cycling.[23, 25, 34] Furthermore, the three phases can form heterojunctions in the interfacial areas (Fig. 3), which will induce an electric field within the nanocrystals, and hence encourage a rapid interfacial ion/electron transfer.[17] In addition to the three active phases, the carbon in the composite can play an important role as well. The effect of the carbon content in the ternary $\mathrm{Sn}_{5} \mathrm{SbP}_{3} / \mathrm{C}$ composite on the $\mathrm{Sn}_{5} \mathrm{SbP}_{3} / \mathrm{C}$ composite was also investigated and the results are shown in Fig. S5. It seems that that the optimum carbon addition in the ternary $\mathrm{Sn}_{5} \mathrm{SbP}_{3} / \mathrm{C}$ composite is 12.5 wt. \%. Considering that the carbon black only delivers a capacity of around $100 \mathrm{~mA} \mathrm{~h} \mathrm{~g} \mathrm{~g}^{-}$ ${ }^{1}$ (Fig. S6), the capacity in the $\mathrm{Sn}_{5} \mathrm{SbP}_{3} / \mathrm{C}$ composite is largely attributed from the three active phases. Nevertheless, the addition of carbon can benefit the cycle life due to its good electric conductivity and buffer effect (Fig. S5). The last, but still important, benefit brought by the 
nano sized multiphase structure of the $\mathrm{Sn}_{5} \mathrm{SbP}_{3} / \mathrm{C}$ electrode is efficient $\mathrm{Na}$ ion transportation, which in turn enhances the performance of the electrode. All these factors synergistically contribute to better capacity and cycling performance and high rate capability by offering high electrical conductivity, fast ion transportation and high structure strength.

\section{Conclusions}

In summary, $\mathrm{Sn}_{5} \mathrm{SbP}_{3} / \mathrm{C}$ composite was successfully synthesized by a facile ball-milling technique. When tested as anode in sodium-ion batteries, the $\mathrm{Sn}_{5} \mathrm{SbP}_{3} / \mathrm{C}$ shows a superior electrochemical performance to the binary $\mathrm{Sn}_{4} \mathrm{P}_{3} / \mathrm{C}$ or $\mathrm{SnSb} / \mathrm{C}$ electrode, especially at higher current densities $\left(500 \mathrm{~mA} \mathrm{~g}^{-1}\right.$ and $\left.1000 \mathrm{~mA} \mathrm{~g}^{-1}\right)$. The excellent electrochemical performance of the $\mathrm{Sn}_{5} \mathrm{SbP}_{3} / \mathrm{C}$ electrode arises from a synergetic effect, which is due to the mutual buffering effect of the multiple phases, the fine grain size of the active phases, the conductive carbon matrix which enhances the integrity and the good electrical conductivity of the electrode. Our results encourage the exploration of superior cycle stable alloy based anode materials through the low-cost, eco-friendly, and scalable ball milling method for rechargeable batteries.

\section{Acknowledgements}

Authors would like to thank Dr. Tania Silver for the reading and editing of the manuscript, and also acknowledge the use of the ARC facilities purchased through FT150100109 and the ARC facilities in the Electron Microscopy Centre of the University of Wollongong (UOW), especially thanks Dr. Gilberto Casillas-Garcia for low temperature HRTEM. The author, Wenchao Zhang, would like to thank the UOW and Engineering Materials Institute of UOW for financial support.

\section{References}

[1] M.D. Slater, D. Kim, E. Lee, C.S. Johnson, Advanced Functional Materials, 23 (2013) 947-958. 
[2] C. Bommier, X. Ji, Israel Journal of Chemistry, 55 (2015) 486-507.

[3] N. Yabuuchi, K. Kubota, M. Dahbi, S. Komaba, Chemical reviews, 114 (2014) 11636-11682.

[4] V. Palomares, M. Casas-Cabanas, E. Castillo-Martínez, M.H. Han, T. Rojo, Energy \& Environmental Science, 6 (2013) 2312-2337.

[5] Y. Wen, K. He, Y. Zhu, F. Han, Y. Xu, I. Matsuda, Y. Ishii, J. Cumings, C. Wang, Nature communications, 5 (2014).

[6] S.Y. Hong, Y. Kim, Y. Park, A. Choi, N.-S. Choi, K.T. Lee, Energy \& Environmental Science, 6 (2013) 2067-2081.

[7] H. Pan, Y.-S. Hu, L. Chen, Energy \& Environmental Science, 6 (2013) 2338-2360.

[8] W. Zuo, W. Zhu, D. Zhao, Y. Sun, Y. Li, J. Liu, X.W.D. Lou, Energy \& Environmental Science, 9 (2016) 28812891.

[9] L.P. Wang, L. Yu, X. Wang, M. Srinivasan, Z.J. Xu, Journal of Materials Chemistry A, 3 (2015) 9353-9378.

[10] Y. Xiao, H. Jang-Yeon, Y.-K. Sun, Journal of Materials Chemistry A, (2016).

[11] J. Chen, G. Zou, H. Hou, Y. Zhang, Z. Huang, X. Ji, Journal of Materials Chemistry A, 4 (2016) 12591-12601.

[12] X. Xu, D. Yu, H. Zhou, L. Zhang, C. Xiao, C. Guo, S. Guo, S. Ding, Journal of Materials Chemistry A, 4 (2016) 4375-4379.

[13] H. Hou, C.E. Banks, M. Jing, Y. Zhang, X. Ji, Advanced Materials, 27 (2015) 7861-7866.

[14] M.K. Datta, R. Epur, P. Saha, K. Kadakia, S.K. Park, P.N. Kumta, Journal of Power Sources, 225 (2013) 316 322.

[15] D.-H. Nam, K.-S. Hong, S.-J. Lim, H.-S. Kwon, Journal of Power Sources, 247 (2014) 423-427.

[16] D. Yan, X. Xu, T. Lu, B. Hu, D.H. Chua, L. Pan, Journal of Power Sources, 316 (2016) 132-138.

[17] Y. Zheng, T. Zhou, C. Zhang, J. Mao, H. Liu, Z. Guo, Angewandte Chemie International Edition, 55 (2016) 3408-3413.

[18] D. Kundu, E. Talaie, V. Duffort, L.F. Nazar, Angewandte Chemie International Edition, 54 (2015) 3431-3448.

[19] E.M. Lotfabad, J. Ding, K. Cui, A. Kohandehghan, W.P. Kalisvaart, M. Hazelton, D. Mitlin, Acs Nano, 8 (2014) 7115-7129.

[20] J. Qian, X. Wu, Y. Cao, X. Ai, H. Yang, Angewandte Chemie, 125 (2013) 4731-4734.

[21] A. Darwiche, C. Marino, M.T. Sougrati, B. Fraisse, L. Stievano, L. Monconduit, Journal of the American Chemical Society, 134 (2012) 20805-20811.

[22] J. Liu, P. Kopold, C. Wu, P.A. van Aken, J. Maier, Y. Yu, Energy \& Environmental Science, 8 (2015) 3531-3538.

[23] I.T. Kim, S.-O. Kim, A. Manthiram, Journal of Power Sources, 269 (2014) 848-854.

[24] J. Mao, X. Fan, C. Luo, C. Wang, ACS applied materials \& interfaces, 8 (2016) 7147-7155.

[25] J. Qian, Y. Xiong, Y. Cao, X. Ai, H. Yang, Nano letters, 14 (2014) 1865-1869.

[26] L. Ji, W. Zhou, V. Chabot, A. Yu, X. Xiao, ACS applied materials \& interfaces, 7 (2015) 24895-24901.

[27] L. Baggetto, H.-Y. Hah, J.-C. Jumas, C.E. Johnson, J.A. Johnson, J.K. Keum, C.A. Bridges, G.M. Veith, Journal of Power Sources, 267 (2014) 329-336.

[28] Y. Kim, Y. Park, A. Choi, N.S. Choi, J. Kim, J. Lee, J.H. Ryu, S.M. Oh, K.T. Lee, Advanced materials, 25 (2013) 3045-3049.

[29] Q. Li, Z. Li, Z. Zhang, C. Li, J. Ma, C. Wang, X. Ge, S. Dong, L. Yin, Advanced Energy Materials, 6 (2016).

[30] B.H. Toby, R.B. Von Dreele, Journal of Applied Crystallography, 46 (2013) 544-549.

[31] W. Li, S.L. Chou, J.Z. Wang, J.H. Kim, H.K. Liu, S.X. Dou, Advanced Materials, 26 (2014) 4037-4042.

[32] H. Kang, Y. Liu, K. Cao, Y. Zhao, L. Jiao, Y. Wang, H. Yuan, Journal of Materials Chemistry A, 3 (2015) 1789917913.

[33] P.R. Abel, M.G. Fields, A. Heller, C.B. Mullins, ACS applied materials \& interfaces, 6 (2014) 15860-15867.

[34] L. Xiao, Y. Cao, J. Xiao, W. Wang, L. Kovarik, Z. Nie, J. Liu, Chemical Communications, 48 (2012) 3321-3323. 


\section{Large-scale synthesis of $\mathrm{Sn}_{5} \mathrm{SbP}_{3} / \mathrm{C}$ composite by ball milling for superior stable sodium-ion battery anode}

Wenchao Zhang, ${ }^{\text {a, }}$ Jianfeng Mao, ${ }^{\text {,** }}$ Wei Kong Pang, ${ }^{\text {b,c }}$ Zaiping Guo ${ }^{\mathrm{b}}$, Zhixin Chen, ${ }^{\mathrm{a},{ }^{*}}$

${ }^{\mathrm{a}}$ Engineering Materials Institute, School of Mechanical, Materials \& Mechatronics

Engineering, University of Wollongong, NSW 2500, Australia.

${ }^{\mathrm{b}}$ Institute for Superconducting \& Electronic Materials, University of Wollongong,

Wollongong, NSW 2522, Australia.

${ }^{c}$ Australian Centre for Neutron Scattering, Australian Nuclear Science and Technology

Organization, Locked Bag 2001, Kirrawee DC, NSW 2232, Australia.

* Corresponding authors

Jianfeng Mao: E-mail: jmao@uow.edu.au, T: +61 24221 5225, F: +61 242215630

Zhixin Chen: E-mail: zchen@uow.edu.au, T: +61 24221 4932, F: +61 242215474 


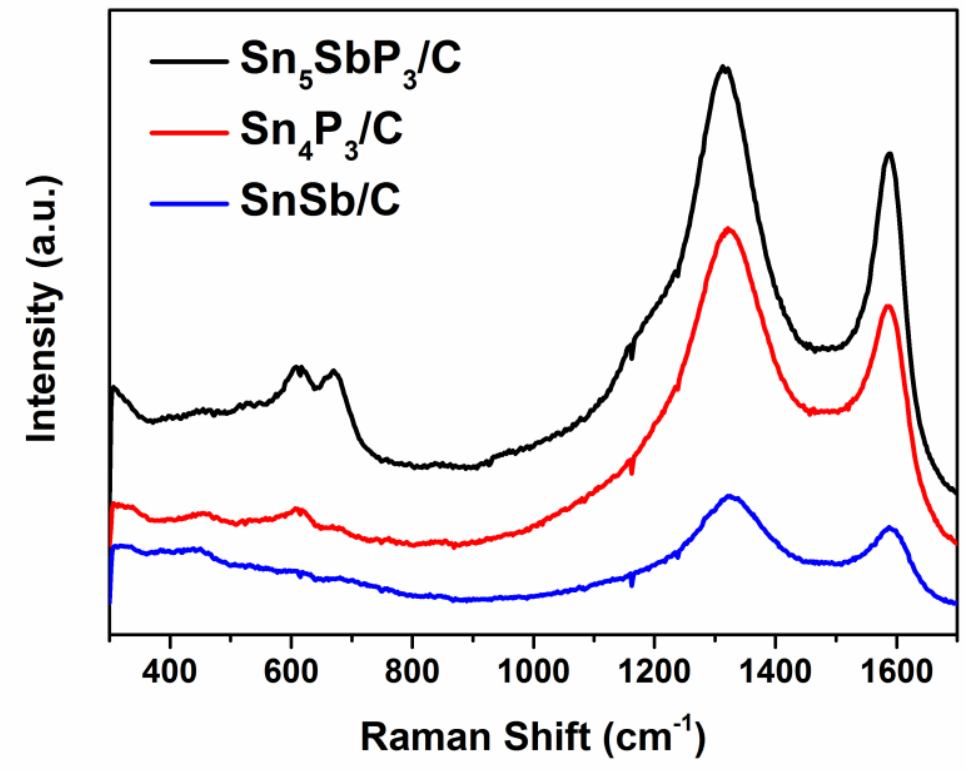

Fig.S1 Raman spectra of $\mathrm{Sn}_{5} \mathrm{SbP}_{3} / \mathrm{C}, \mathrm{Sn}_{4} \mathrm{P}_{3} / \mathrm{C}$ and $\mathrm{SnSb} / \mathrm{C}$ powder 

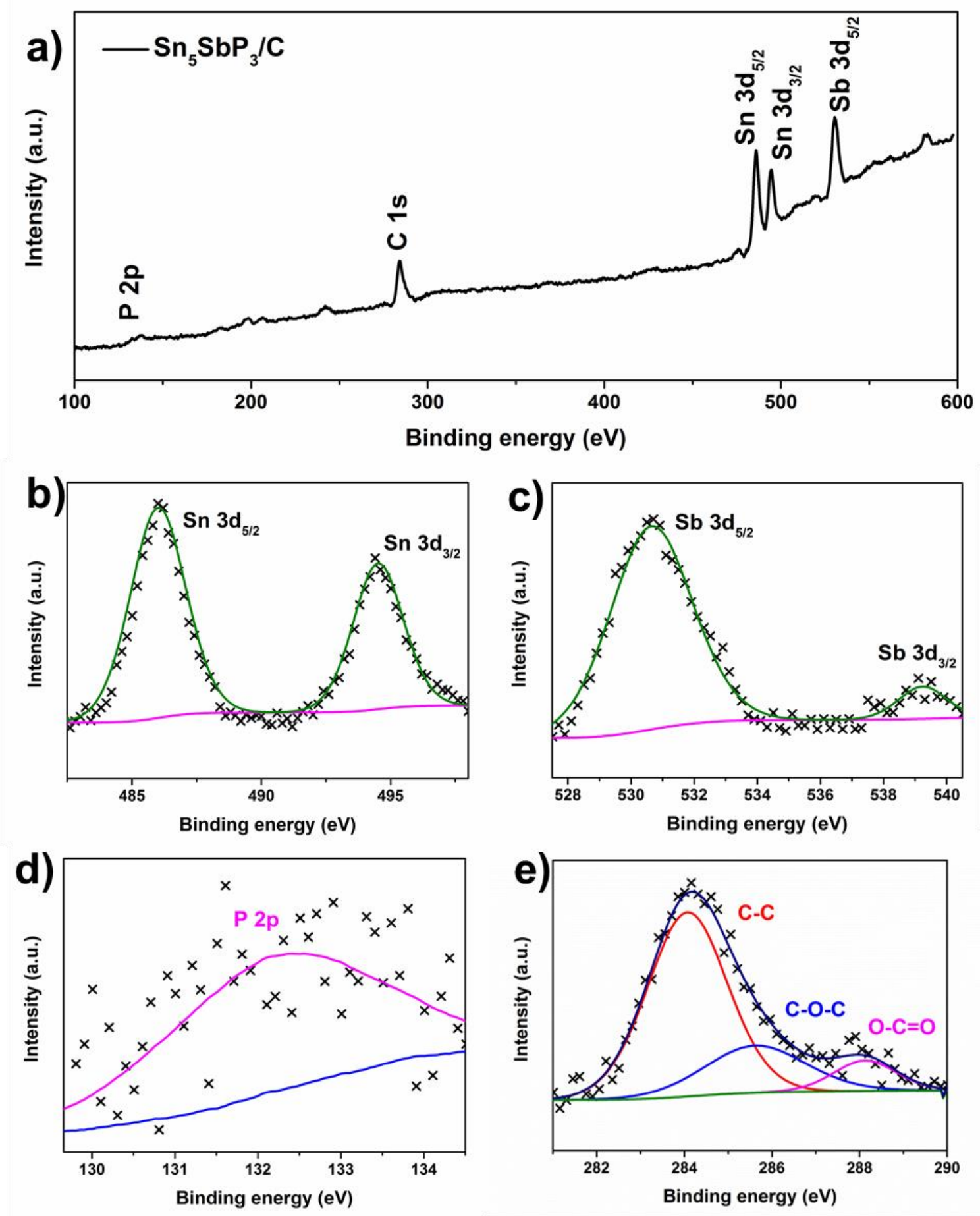

Fig. S2 a) Typical XPS survey spectra of the $\mathrm{Sn}_{5} \mathrm{SbP}_{3} / \mathrm{C}$ and the corresponding b) $\mathrm{Sn} 3 \mathrm{~d}$ c) $\mathrm{Sb}$ 3d d) P 2p and e) C 1s XPS spectra 

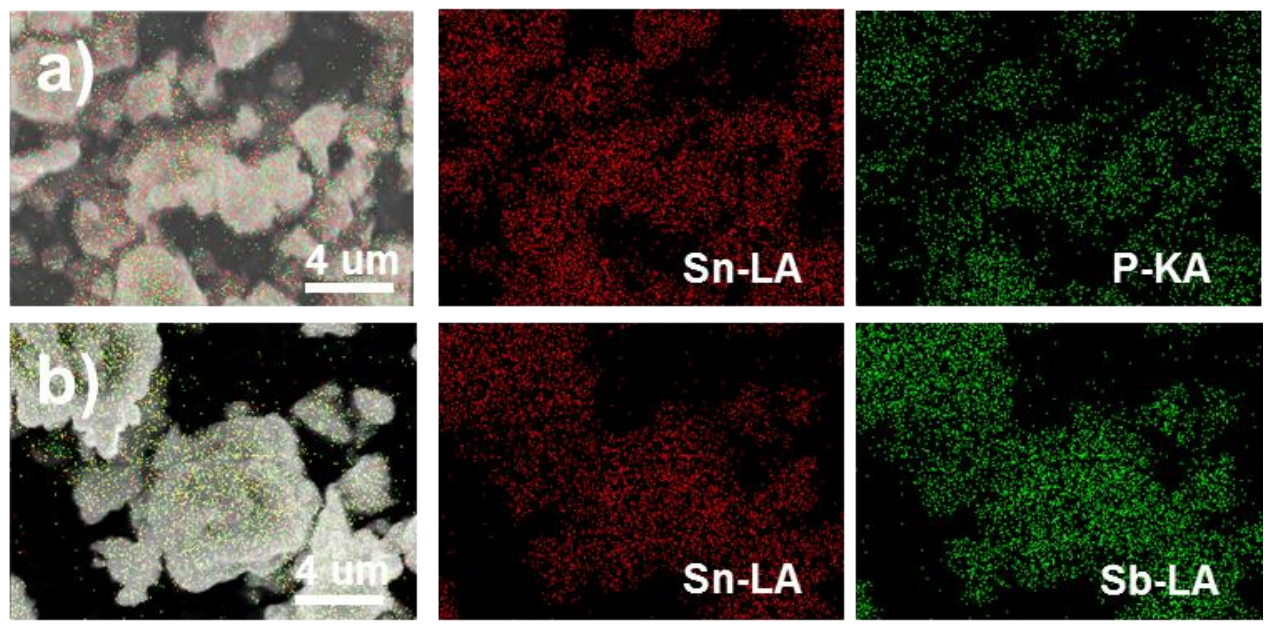

Fig. S3 EDS mapping of a) $\mathrm{Sn}_{4} \mathrm{P}_{3} / \mathrm{C}$, b) $\mathrm{SnSb} / \mathrm{C}$ powders 

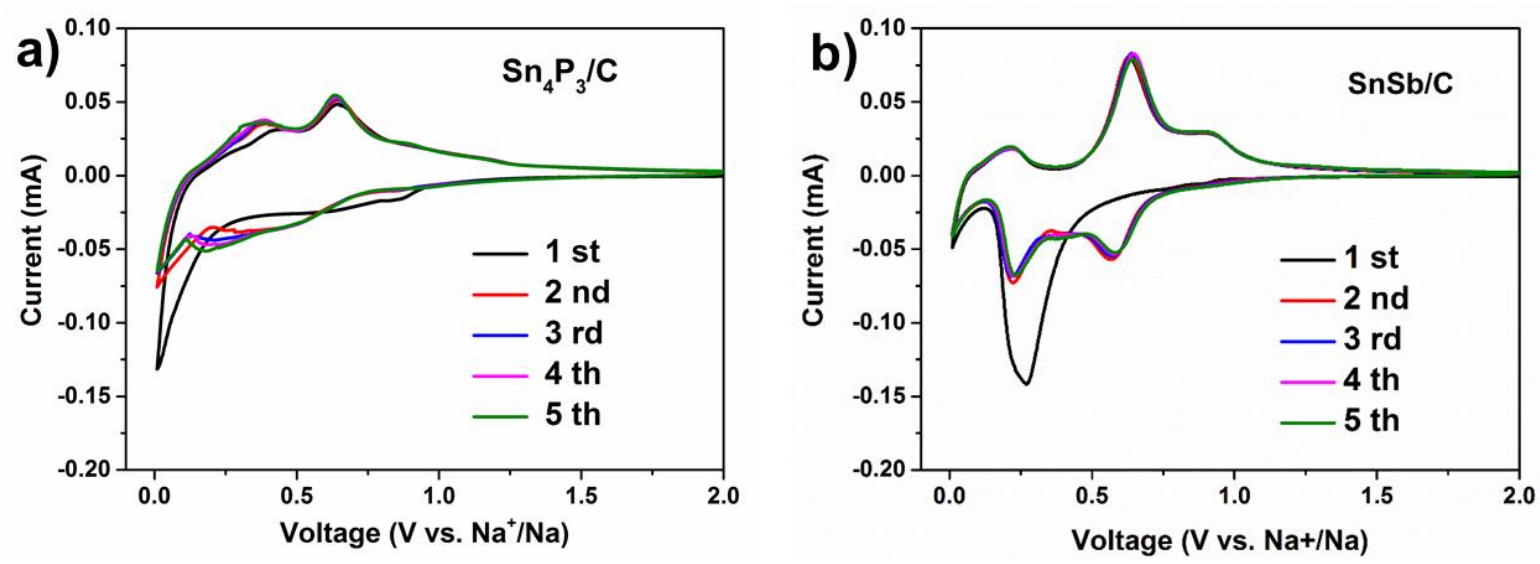

Fig. S4 Cyclic voltammograms of a) $\mathrm{Sn}_{4} \mathrm{P}_{3} / \mathrm{C}$, b) $\mathrm{SnSb} / \mathrm{C}$ electrodes tested at a scanning rate of $0.05 \mathrm{mV} / \mathrm{s}$ 

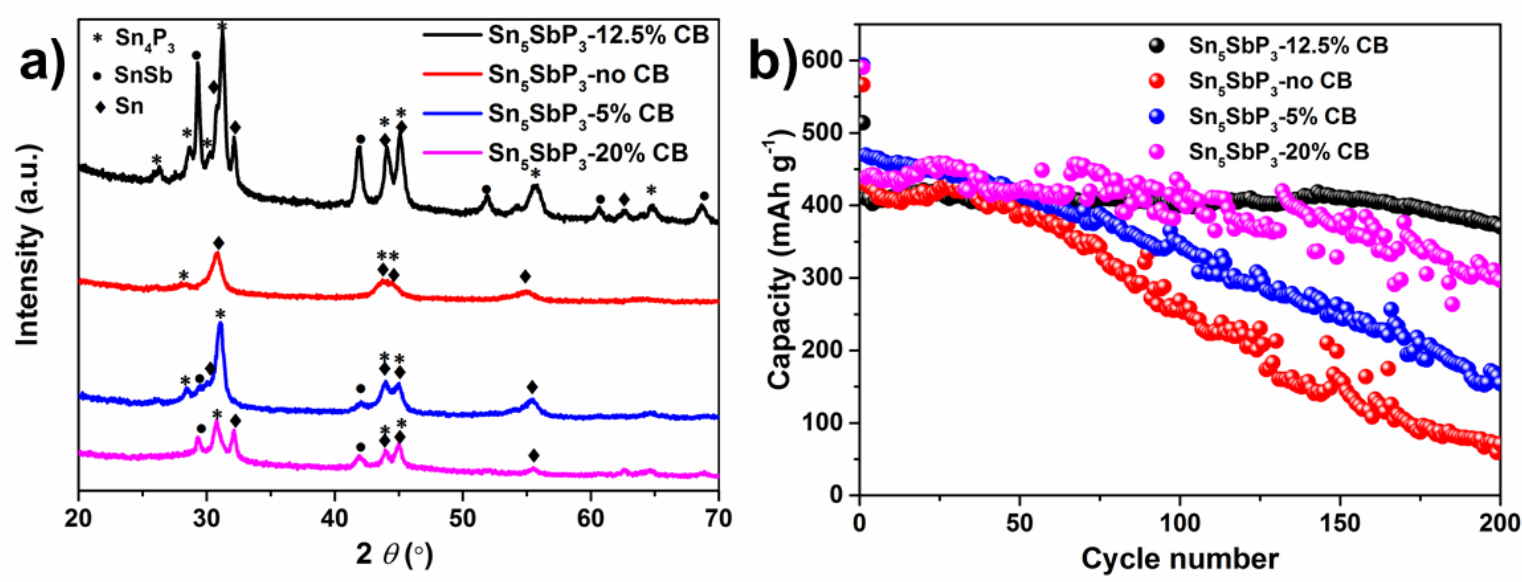

Fig. S5 a) X-ray diffraction (XRD) patterns and b) Cycling performance at the current density of $1 \mathrm{~A} \mathrm{~g}^{-1}$ of $\mathrm{Sn}_{5} \mathrm{SbP}_{3}-12.5 \%$ carbon black (CB), $\mathrm{Sn}_{5} \mathrm{SbP}_{3}$-no carbon, $\mathrm{Sn}_{5} \mathrm{SbP}_{3}-5 \%$ carbon and $\mathrm{Sn}_{5} \mathrm{SbP}_{3}-20 \%$ carbon 


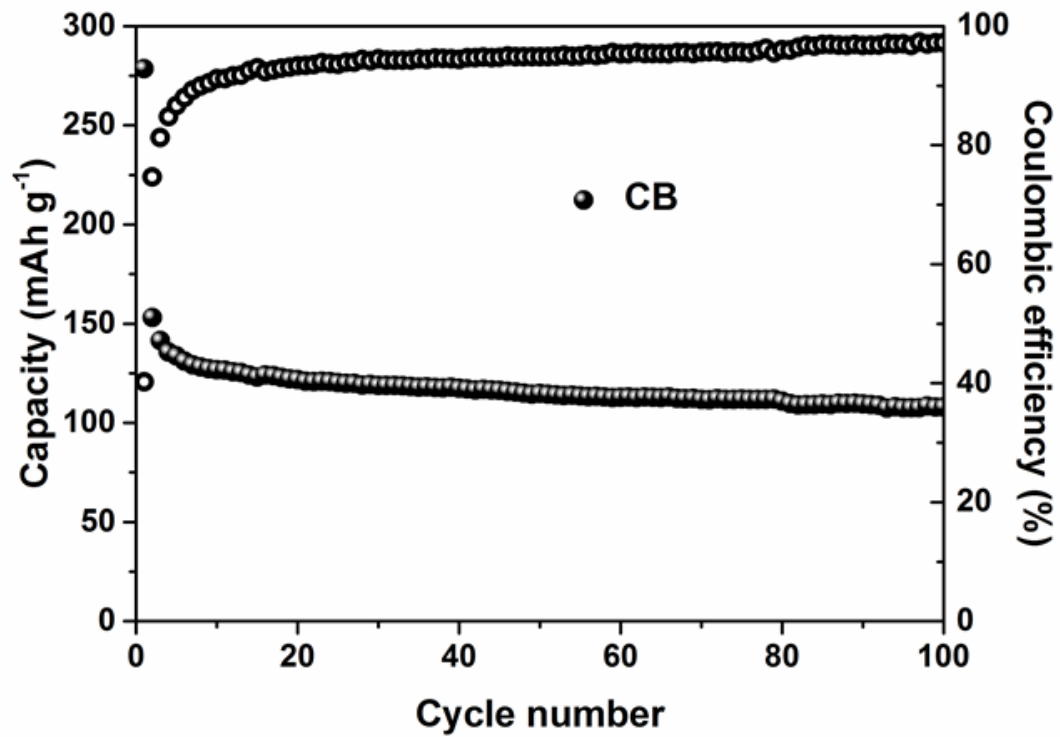

Fig. S6 Cycling performance of carbon black (CB) at the current density of $100 \mathrm{~mA} \mathrm{~g}^{-1}$ 


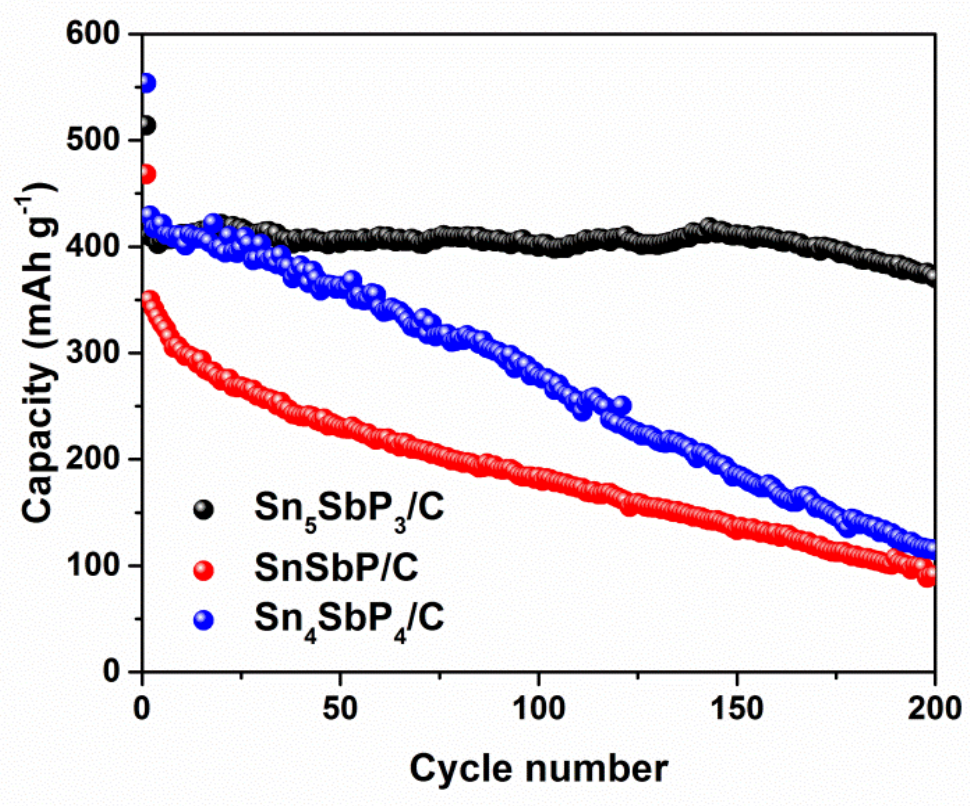

Fig. S7 Cycling performance at the current density of $1 \mathrm{~A} \mathrm{~g}^{-1}$ of $\mathrm{Sn}_{5} \mathrm{SbP}_{3} / \mathrm{C}, \mathrm{SnSbP} / \mathrm{C}$ and $\mathrm{Sn}_{4} \mathrm{SbP}_{4} / \mathrm{C}$ 

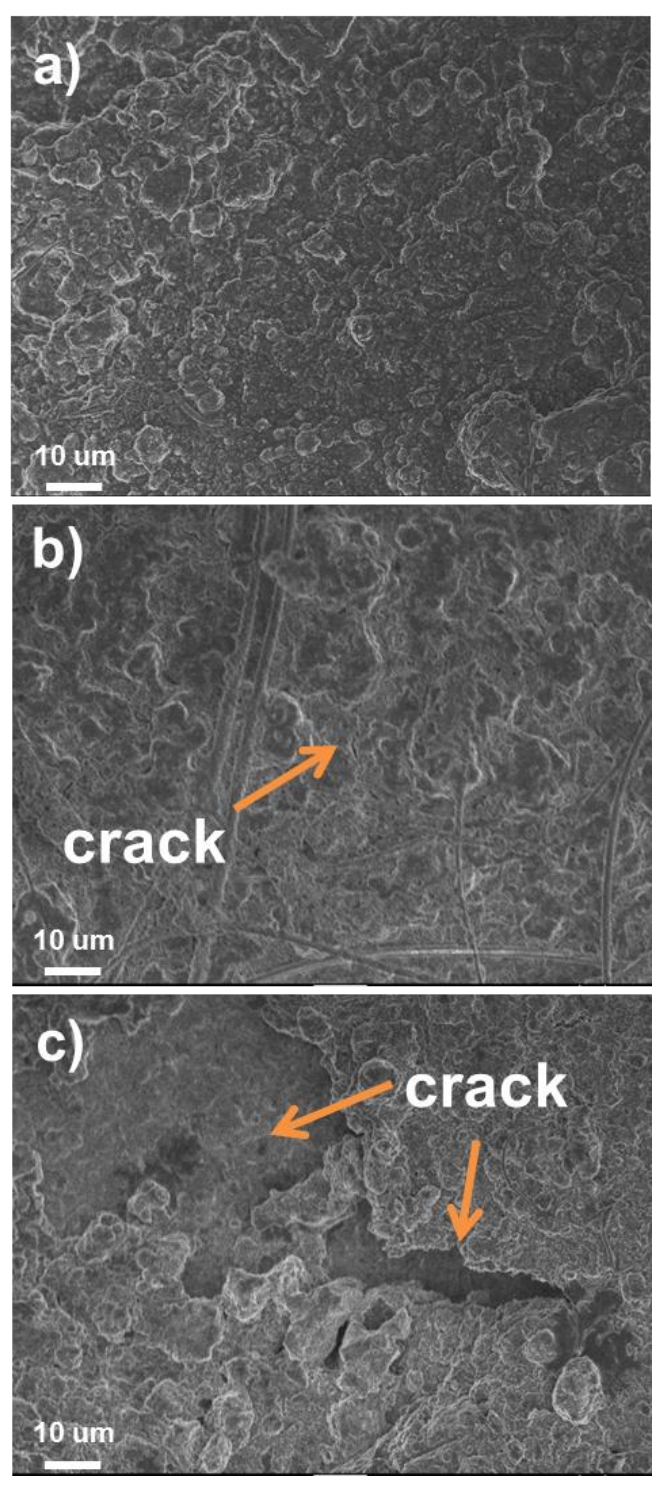

Fig. S8 FESEM images (1000X) of a) $\mathrm{Sn}_{5} \mathrm{SbP}_{3} / \mathrm{C}$, b) $\mathrm{Sn}_{4} \mathrm{P}_{3} / \mathrm{C}$, c) $\mathrm{SnSb} / \mathrm{C}$ after 100 cycles at $1000 \mathrm{~mA} \mathrm{~g}^{-1}$ 


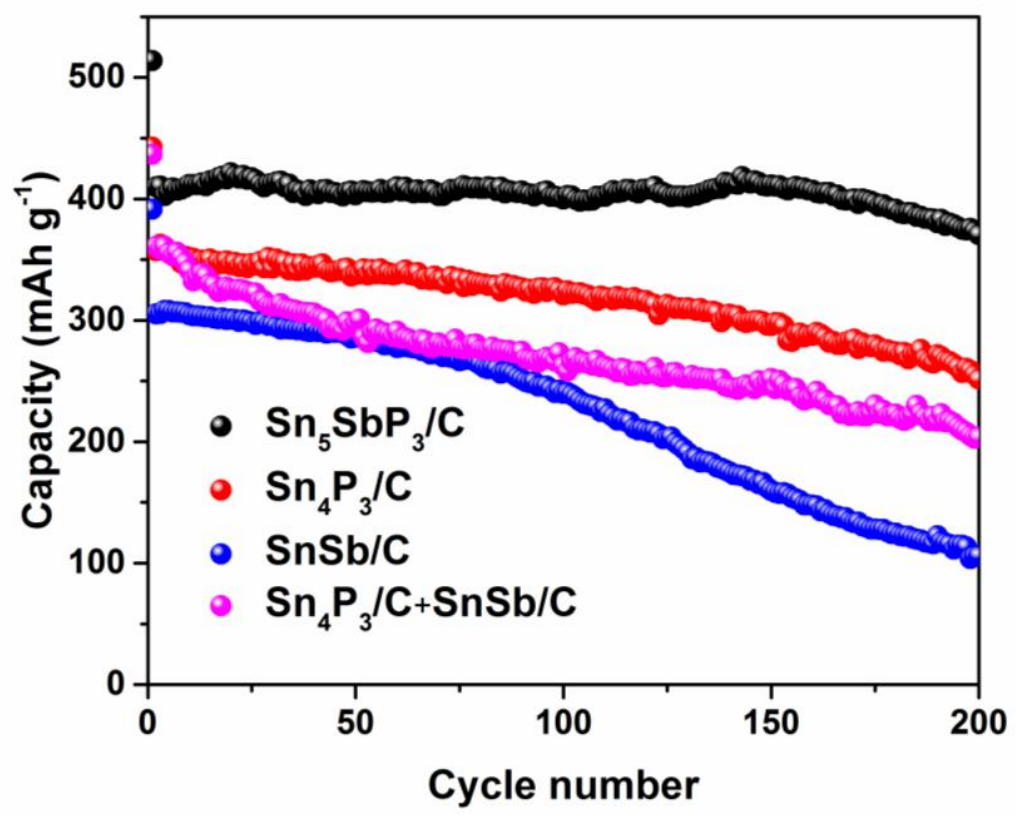

Fig. S9 Cycling performance at the current density of $1 \mathrm{~A} \mathrm{~g}^{-1}$ of $\mathrm{Sn}_{5} \mathrm{SbP}_{3} / \mathrm{C}, \mathrm{Sn}_{4} \mathrm{P}_{3} / \mathrm{C}, \mathrm{SnSb} / \mathrm{C}$ and $\mathrm{Sn}_{4} \mathrm{P}_{3} / \mathrm{C}+\mathrm{SnSb} / \mathrm{C}$ 
Table S1 EDS mapping composition of three different powders in wt.\%

\begin{tabular}{cccc}
\hline & Sn-LA & Sb-LA & P-KA \\
\hline $\mathrm{Sn}_{5} \mathrm{SbP}_{3} / \mathrm{C}$ & 73.55 & 16.31 & 10.13 \\
$\mathrm{Sn}_{4} \mathrm{P}_{3} / \mathrm{C}$ & 86.24 & & 13.76 \\
$\mathrm{SnSb} / \mathrm{C}$ & 48.82 & 51.18 & \\
\hline
\end{tabular}

Table S2 Comparison electrical conductivity of Sn, Sb and P

\begin{tabular}{ccc}
\hline Element & Electrical conductivity $\left(\mathrm{S} \mathrm{cm}^{-1}\right)$ & Theoretical capacity $\left(\mathrm{mA} \mathrm{h} \mathrm{g}^{-1}\right)$ \\
\hline $\mathrm{Sn}$ & $9 * 10^{4}$ & 847 \\
$\mathrm{Sb}$ & $2.5^{*} 10^{4}$ & 660 \\
$\mathrm{P}$ & $1 * 10^{-14}$ & 2596 \\
\hline
\end{tabular}

